\title{
Degradation and environmental risk at the Diamond Zone, Acapulco, Mexico
}

\author{
H. Avilez, T. Rivas \& E. Chavarría \\ Unidad Académica de Turismo, \\ Universidad Autónoma de Guerrero, Mexico
}

\begin{abstract}
The list of selected temporary or permanent residents in the geographical area identified as Diamond adjacent to the destination Acapulco, Mexico is a private community meant to be a draft Integrally Planned Center (IPC), a paradigm of the Mexican resort presents inexorable problems contributing to environmental degradation, due to the lack of sufficient water and sewer systems, fractured septic drains create run off which inevitably leaks into the groundwater, causing very low level contamination. Waste water treatment plants that are entrenched rendering them useless, resulting in the raw water running to the sea that threatens to impact the coastal zone degrading a coastal resource gradient, providing ballast which constitute the misfortune of corrupt governments in resource-hungry bypassing the alteration which is a violation of nature away from the precepts of sustainability. The rationale for implementing a development enclave was a scheme that compelled speculation and corruption to the nuclei of replicating native build shanty towns. Residents absent from the underlying problems of territoriality, which expresses the reality between society and the environment, where entrepreneurs unconsciously destroy, build and abandon land by altering the use, ignoring the environmental impacts incur authorities colluded with leniency to the regulations in protecting biodiversity. The research analyzes and provides information, linking reflection and debate on territorial dynamics and problems of the socio-economic, territorial and environmental, as a result of changes in the pattern of urbanization, commercialization, turbulence emanating that the authority dismissed as Agenda 21 (Rio de Janeiro, Brazil 1992) and environmental impunity.

Keywords: environmental degradation, treatment plants, environmental impacts, shantytowns, land expropriation, development model.
\end{abstract}




\section{Introduction}

The city and port of Acapulco, Mexico, located in the southeast of the state of Guerrero, is to Mexico one of the major tourist destinations of sun and sand of mass concentration and which historical records evidence its official founding in 1532 , it begins as a small fishing village, quiet peaceful, full of traditions and strong cultural identity beginning in 1927 , to establish connectivity with the city of Mexico through the construction of a road to connect the great capital with the emerging Mexican tourist destination in the Pacific Ocean.

As Mexico's President Adolfo Ruiz Cortines (1952-1958), according to Orteiza [1] Acapulco was transformed, the streets of the city center were lined up, was formally concluded the main avenue the Costera Miguel Aleman, built the first City Airport, the scenic road, the fountain of the Diana, the new Federal Palace and the great work the international airport, the beautification of the iconic beaches Caleta and Caletilla destination, and more works that began Acapulco's genesis as the paradise of the Americas.

Also initiated the dispute of land and most stunning landscapes of what Acapulco's bay is, as Mexico's flagship tourist destination and main source of income from tourism in the State of Guerrero, from the decade of the 1930s it has been transformed steadily, with a vertiginous growth becoming an enclave mirror to migrants from the state and other regions of the country, in search of opportunity and the dream of obtaining secure employment and good wages, that have not always met expectations of the vast majority. It was the year of 1934 when it promoted the building of the first hotel in the port, despite the tortuous journey that people had to do from Mexico City. Even when they did a one week journey, there were travelers who had ventured to come (Escudero [2]).

To Acapulco the years 1960 and 1970 were the birth of wealth, in the favorite vacation spot of the so-called great elite. During the year 1970 are created the subdivisions Las Brisas, Brisas Guitarrón, Brisas Marquez, harboring the most luxurious homes of businessmen and national and international artists. In the decade of the 80 s Acapulco clearly enjoyed the best season of popularity and success in service industries opening many foreign-invested enterprises and micro-locally, and since then until now have been exploiting and disparaging natural resources, cultural to the leniency of the regulations.

The Guerrero state government led by the tourism boom created the conditions conducive to expropriate the lands of helpless farmers against the power of the hegemonic state, which were the suburbs of Copacabana through successive expropriation decrees the first of June 12, 1992 "is declared of public utility and decreed the expropriation in favor of decentralized agency of the government of the state of Guerrero, Guerrero's Tourism Promoter, the land without construction, located in the Tourism Integration known as Diamond Zone in order that meets the objectives envisaged in the promotion tourism law". Again for September 8, 1992 and it strikes the final blow September 25, 2001 for a total of $321,842,967.1 \mathrm{~m}^{2}$.

As governor of the state of Guerrero, Alejandro Cervantes Delgado (19811987) began with greater momentum the despoil of common lands to the 
inhabitant settlers of the main town of Copacabana, farmers were cheated, because they were informed that they would respect their property titles, however, they soon began to be bullied into abandoning the prized area of coastline that wealthy entrepreneurs coveted and start legally the plunder of the inhabitants.

The scene suddenly changed for farmers being informed later in a general assembly of farmers that a state government dependence was created named Guerrero's Tourism Promoter at that time was 1988, where again the common land commissioner summoned them to confirm of that dependence.

In exchange for ceding their land the state government promised them other lands with the same square meters already owned, which ultimately proved to be the nursery colony located near the airport of the city, with boundary in the lagoon three-pronged, where the authority committed to provide the public services of potable water, sewer, street paving, parks, schools, churches, and markets. Commitments were fallacies because the state government never fulfilled, the colony is converted into a belt of misery without water, drainage, whose streets are converted lagoon areas often preventing them from leaving their homes because of floods that they are subject to in times of rainfall, coupled with the health problems of flies, infections from traveling on the water and inconveniences associated with infectious diseases.

From that time the villagers would live with moments of high tension and uncertainty by the profuse spread of rumors and lack of reliable information from the authorities who claimed to be representatives of the government as their representatives of the common land's commissary. So without official guidance and uneasiness they were involved at times when prevailing hegemonicdictatorial governments where the non-governmental organizations (NGOs, S) did not exist and what the government said was fulfilled, and those who were against it faced deadly consequences.

However, the Copacabana's peasants have maintained a long resistance for more than two decades and persist in their claims and litigation against the government of the State of Guerrero. As a result of the research under investigation, they are trying to rebuild the episode of the controversial expropriation with interviews, of the original owners or descendants of relatives, by the absence and in several cases by the death of the original owners. We found horror stories that relate the harassment of peasants who were arrested from 1988 and lasted about a year before being dislodged violently, because they ultimately resisted to the end, intimidated day and night by the army, burning their homes, hitting their families, shooting into the air, cutting off their electricity, water, hindering the exit and entrance to the ejido, causing panic, despair to provoke frontally and confront the military risking their lives (Cruz et al. [3]).

Beginning in 1989, Acapulco was fragmented geographically according to its tourism development in three touristic zones: Traditional Zone, Golden zone and the genesis of the Diamond Zone, and in this last one in an accelerated manner have made significant construction investments, providing the rise of the most expensive and private zone in the port of Acapulco. For this purpose it has been 
attracting tourists for second homes and weekends essentially, by selling lots of houses, villas, condos and apartments in the extra-hotel area that offers approximately 16,000 thousand rooms of second residence (Zapata and Agaton [4]) - totally misrepresenting the substance of expropriation.

The Diamond Zone as Acapulco's third geographical zone to exploit that advantage and now considered the largest added value zone faces severe problems, however, that its creation was to generate a model of fully planned development. The expectations have not been met, due to a disproportionate urban growth, creating overcrowding in both the coast and moor area where the population centers of high social marginalization have spilt over, is evidence of social exclusion suitable to the greed of savage capitalism.

Acapulco's Diamond Zone, is certainly of extraordinary contemplative beauty, that now faces serious problems, first with the legality of the fraudulent expropriation of the land, had lack of studies of the soil use and environmental impact studies because everything was circumvent by the only force that ruled in an hegemonic way that governed the country the Institutional Revolutionary Party (PRI). The expropriated lands which have built many infrastructures poorly, exceeding the construction of additional housing type hotel, this coupled with poor distribution of basic services for the neighboring population, and the inevitable pollution that is the main subject source of income for local fishermen through its main body of water the lake of three masts component of the Diamond Zone.

\section{Frame of reference}

Expropriation is an institution of Mexican Public Law, which is coercive transfer of private property from its owner to the State, acting under authority of legislative or executive, on payment of compensation, concretely, a public administration body endowed of its own assets. Can a property be expropriated for it to be operated by the State or by a third party?

According to the above, it is valid to ask. Why the state is involved in tourism development? And what are the reasons for its intervention? The centralist tradition and interventionist state in civil society, allows us to look at the expropriation as an engine of tourism development in the country, likewise the bases argued in Article 27 of the Constitution of the United Mexican States in which it says that ownership of lands and waters within the boundaries of national territory, it is originally to the nation which has had and has the right to transmit title thereof to private persons, thereby constituting the private property. Expropriation may be made only for reasons of public interest and through compensation. The nation will always have the right to impose to the private property the modalities that dictate the public interest dictates [5].

It is through this legal figure that the government expropriated large natural areas, paradisiacal landscapes especially at the coastal areas to cleave a temporary source of resources from the sale of the land taken from peasants, upholding the public interest, to sell to hotel groups and real estate under the premise of creating jobs, direct and indirect that the population demand and the 
so desired currencies that promise to bring the international tourism to correct and promote the regional development that appears to improve the welfare of recipient populations.

\section{The mutation to space tourism and beginning of environmental degradation}

Peasants who have expropriated their land for tourism purposes by enjoying unparalleled scenic setting, where they lived from cultivation of ornamental plants as micro entrepreneurs, to become employees with meager salaries of the tourism developers of the supply of apartments, second home condominiums, undermining their future, their lifestyle, for which the Guerrero state government explicitly creates the Promoter Tourism (PROTUR) which substantive purposes were for generating the necessary services to the tourism use of that territorial space, as roads, electrification, and the necessary infrastructure to attract investment and high economic capacity buyers.

The massive construction of condominium buildings of extra-hotel offer in the area, has attracted investment benefits to the state, of even modest impact on the population by the poor manpower and devastating consequences for zones not yet quantified or ignored by authorities arranged to instant profit when Leff [6] warned that the state's response to the deterioration process had been delayed, particularly before its quick rhythm and its cumulative character, since the government reasons to expropriate were to create protected areas, ecological zones and reserves for the future hotel growth of Acapulco so the expropriation of $321,842,967.12$ meters square of land to farmers, was a deception of the state to take the land and sell it to the highest bidder, although this did not deliver the promised jobs, so there was a wildness to rise in the supply of second homes, though this were not given off to forge hotel jobs, radically changing land use, ignoring environmental impacts, just as he becomes the Summit of Rio de Janeiro (1992) of the results emanating from a number of recommendations for preservation of biodiversity and attention to coastal destinations. The Mexican government arbitrarily deprives farmers to generate more poverty belts leaving them without family support.

For decades tourism has severely impacted ecosystems with its massive resort strategy, where the sun and the beach has been the shelter for touristic movements; at the same time, for the avid destinations of foreign exchange causing the panacea to resolve economic hardship. Though, Escobar [7] says that the reign of abundance that tourism activity promised has produced the opposite: misery, massive underdevelopment, exploitation and oppression. Before this context, the activity has the challenge to apprehend and internalize that it is not living in an age of changes, but a change of age, marked by a healthy planet's social and ecological risk. Today's tourism reality traduces in destinations with sick natural and urban landscapes because of socio-environmental problems, urged to rectify mistakes before the lack of economic resources are a bridle for return to sustainable destinations. 
Such is the case of Acapulco Diamond Zone where people ignore the big environmental problems that are generated by real estate development that grows hurriedly with an unlimited environmental impunity, where more than 50 developments for touristic attractions has no drains, discharged into septic tanks over 15 years old, fractured without maintenance, whose black water runoff penetrates through the ground contaminating groundwater, sand and beaches. Velazco [8] admitted that cleaning tasks are insufficient to meet the requirements of the certification standard of beaches, because in the most recent samplings were quantified up to 54 solid wastes in one square meter, while the standard stipulates that there must be less than 5 residues per $100 \mathrm{~m}^{2}$. In holiday periods like holy week and New Year's Eve, low budget tourists are installed in dozens of tents on the beach, generating trash, and using the beaches as outdoor toilets.

The monitoring that Secretaría del Medio Ambiente y Recursos Naturales (SEMARNAT) [9] makes about water quality in the beaches like Caleta, Caletilla and Hornos exceed the amount of solid wastes allowed for the enjoyment of the beach water to human use, these results are published in nationwide newspapers, impacting a negative image of the destination.

Apparently all the developments have wastewater treatment plants, but the reality is devastating when it is found that most are in poor condition or out of service forcing download at night the raw water to the beaches in a total collapse of what is now a Diamond Zone awe, whose perspective was impelling an archetype of order and sustainable development, aspiration far away from reality that prevails in that space tourism, a rhetoric to what it states (Ahumada [10]) the primary capital to be a tourism and ecotourism power, is precisely the preservation of natural resources and its sustainable use as a strategy. In summary the Diamond Zone presents significant flaws in the quality of water supplied to the floating population, for this is extracted from the ground where it returns a few hours after closing, a vicious circle, where lies the grave risk of environmental degradation of rivers, lakes and beaches of devastating consequences for the destination. According to the Comisión Nacional del Agua (CONAGUA) [11] the Savannah River adjacent to the area is closed for 30 years by the high pollution, despite a population of 300,000 inhabitants make use of its waters, lacking drinkable water.

\section{What to do about the dilemma: Ethics or economics?}

Exhaustion and the negative consequences of a tourism model, technological changes and management of tourism activity, environmental awareness of many of the social factors, together with greater demands and needs of the tourism demand, leading to a growing appreciation of environmental quality and touristic of the tourism resources in general. Tourism and the environment is the subject of much thought and very few actions, such as ignoring (Pereyra et al. [12]) the major problems that create real estate developments, with its most striking visual impact in the hotel zone, but the biggest impact, the most serious is hidden behind the misery, which is considered as something natural and derived from it 
the suicide, violence against women, drug addiction, and a host of social ills that threaten the extinction of thousands of people.

The indices that reflect the touristic environmental degradation manifested a degree of alert to everyone involved a process of emerging change, unfortunately this phenomenon called the next tsunami will affect with major consequences the poor countries and will immerse millions of habitants in the harrowing arms of poverty (Bernard [13]). Environmental degradation triggered and filled with yearning to boost regional development of nations has assumed the enormous risk of economic collapse and the evolution of inequality and poverty. Sustainability for its emergency has been a mitigation of a fundamental flaw in the history of mankind (Leff [14]) which is now undergoing a severe crisis of the entire civilization is traced across the globe.

The shantytowns are formed naturally by the exclusion that tourism brings to the intransigence associated of the Mexican government to implement the scheme to expropriate from north to south of the country the most beautiful coastal areas to appropriate them displacing thousands of peasants encouraging them to migrate to the USA to the major cities and the rich tourist development poles. In addition, derived from social movements and flows of migrants attracted by the mirage of tourism seeking employment whatever, facing social rejection, emerging poverty cores, forming colonies without water, sewer, garbage collection, with outbreaks of everyday violence, where you only live to survive, affecting rainfall courses, contaminating underground water, forging open garbage landfills, is the prevailing paradigm in Diamond Zone.

In the Diamond Zone, affecting not only ecosystems but worsened in the long term possibility of restoring the broken, with a floating population of over 50,000 residents/tourists cannot yet be determined how deep the groundwater was covered by the runoff of wastewater calculated by the Secretaria del Medio Ambiente y Recursos Naturales (SEMARNAT) in 4million cubic meters annually emptied the basement of a territory that will now have to expect the unexpected, given that the symptoms that reflect environmental degradation express a process of change in a complex system unexpected that depend on the capacity for self-purification of the environment, however the consequences may be unknown to the medium and long term, this process of change could then be defined as the risk that is the probability development of a threat with relatively serious consequences (Pereyra et al. [12]).

Environmental degradation is fed by multiple social factors, processes, speeds, territorial and environmental supports, as well as political contexts, economic, demographic and social associated to populations beyond their environment at the low per capita education become indirect predator agents, before complacent authorities and unable to provide the minimum subsistence services, exacerbating the contaminant spectrum, pushing unhealthy diseases such as, gastrointestinal parasites, skin lesions, dengue fever, acute respiratory infections, all derived from contaminated water with high levels of faecal or water logging due to lack of drainage. 


\section{Environmental impunity due to the lax regulations}

Derived from the Constitution of the United Mexican States and international treaties Mexico has signed, in the country is the General Law of Ecological Balance and Environmental Protection (LEGEEPA) [15] that establishes the right to grant the right of everyone to live in an environment adequate for their health and welfare, to define the principles of environmental policy and instruments for use, preservation, restoration and improvement of the environment, preservation and protection of biodiversity and the establishment and management of protected areas, sustainable use, preservation and where appropriate, restoration of ground water. Article 4 of the Constitution states that everyone has the right to an adequate environment for their development and welfare, that is a matter for Mexico there was not a slide of the environmental crisis, however, lack of transparency, accountability and simulation have the country in environmental impunity.

The current Secretaría del Medio Ambiente y Recursos Naturales (SEMARNAT) promotes the destruction of mangroves, as amended the NOM022-SEMARNAT-2003 [16] relative on the protection of coastal wetlands just by the pressure of tourism developers in Mexico. This amendment establishes that upon payment of financial compensation it is possible to ignore the measures for which the mangroves were protected.

Agenda 21 for Mexican tourism resulting from the Earth Summit in Rio de Janeiro (1992) [17] is a program that proposes strategies and actions to strengthen the dynamics of the tourist regions, including local communities in economic activities generated and ensure the preservation of natural and cultural resources of the Mexican tourist destinations, however, in the Diamond Zone there is no application on the recommendations of Agenda 21, constituting the zone in the area of social exclusion. That has even tried to close the entrances to the population and only civil resistance has achieved that people have limited access to the beaches of the area even when the constitution of the Mexican Republic establishes that the coastal zones belong to the nation, evidence that premium the traffic of influences and economic monopolies.

Undoubtedly that for Mexico the tourism is economic primacy, source of income, employment, according to the Plan Nacional de Desarrollo, PND 20072012-Tourism [18] one of its main substantive destinations is sustainable. Everyone agrees on that and the need to develop rapidly, therefore, why do you resort to practices that favor the economic over the ethical? The question of substance is then, why are prescribing policies that contribute to the development of responsible and sustainable tourism? If it was, Mexico would not be in the slide of negligence incurred by governments at all levels to authorize permits that violate the regulations, as repeated changes in land use that threaten mangroves, wetlands, which consequences may be unknown. This process of change could then be defined as the risk of the likelihood of a threat with unexpected consequences for coastal areas, when it violates the norm NOM-022.

You could say that environmental degradation increases the possibility of disaster. The risk components are the threat and vulnerability. Pereyra et al. [12] 
by threat means the probability of occurrence of a potentially disastrous event for a certain period of time at a given site (Cardona [19]) the vulnerability is defined as the inability of a community to absorb by tuning the effects of a given change in their environment.

The General Law of Ecological Balance and Environmental Protection, establishes a framework for the operation of new tourism development based on the preservation and exploitation of natural resources, and its chapter on the Natural Protected areas, rule the use of sustainable tourism availing, its importance is relevant when tourism development involves endemic ecosystems with respect to which the proliferation of malls and tourist shops forces to question the reason for the inefficient application of this law in Mexico (Jiménez [20]).

Taking into account the different theoretical approaches, meets regularly and point out that public policies are a set of intended decisions which intention is the distribution of certain goods or resources within a historically determined social system. In this distribution process at stake are assets or resources that may affect or extend privileges to certain individuals and groups.

There is an important modality in relation to the definition of public policies and is the question of what the states decide to not do. Arias [21] says this does not mean that the act is not a public policy, but the decision not to act before a given problem is itself a public policy.

Because as noted by Kauffer [22] the public policies should define the rules and guidelines of the highest category in a given subject and in many cases must be registered with the constitutional basis or in the set law itself. Public policies should take into account differences of opinion, consensus and disagreements; citizens should have the opportunity to participate in its management, design, implementation and evaluation.

Unfortunately, the position of Kauffer [22] is more utopia than a reality for most towns. Everyday life is centered, mainly, in the second approach: public policies in several countries in the Americas respond and correspond to the interests of the game reserves of power, which are not even denominated classes, since the process of neoliberal globalization has focused and concentrated in an extremely accelerated way, wealth in ever fewer hands, high-impact resorts like Acapulco Diamond Zone are evidence.

Recent studies by Foley [23] have presented research results have calculated safety limits for nine key environmental processes that could disturb or even prevent, the planet's capacity to house human life. The essential premise arises: Is humanity approaching a global tipping point that would lead to harsh new global environment, oblivious to anything seen before in human evolution?

Another aspect not to be overlooked is the profound interrelationship between the various environmental processes, abounding, no solution can address these environmental processes in isolation, whereas in a fragmented way the various limits, there is a strong link between processes with their consequent limits. If not addressed comprehensively by the countries and the specialized agencies are acting piecemeal, scattered, which seems to lead inevitably to the Tower of Babel. The tourist as being dialectical and tourism and recreational activities 
covering aspects of the human being if it contributes to environmental change invariably act or omission, because even with all international agreements, policies and local laws, speeches, organizations and initiatives on sustainable tourism human being in his role of entrepreneur in tourism, the worker or tourist is directly responsible for the destruction of what he likes and enjoys as a tourist on holiday: the environment.

The following table shows the interpretation of the correlation between the key players that enable Mexican tourist accomplished fact in the Diamond Zone of Acapulco, to put in serious environmental risk and the national vision of tourism development that has permeated policy country and its responsibility, in the niche that you have inflicted on the country's tourism appeal.

Table 1: $\quad$ Matrix model components of Mexican resorts. Authors.

Components of the Mexican tourism development model.

\begin{tabular}{|c|c|c|c|}
\hline $\begin{array}{l}\text { State vision } \\
\text { entrepreneur }\end{array}$ & $\begin{array}{l}\text { Participation of tourism } \\
\text { entrepreneur }\end{array}$ & $\begin{array}{l}\text { Worker participation } \\
\text { of tourism }\end{array}$ & Action of the tourist \\
\hline \multicolumn{4}{|c|}{ Regional development } \\
\hline Select tourist areas & $\begin{array}{l}\text { Investment generates } \\
\text { expectations }\end{array}$ & Little involvement & New offer \\
\hline $\begin{array}{l}\text { Expropriate peasant } \\
\text { land for tourism }\end{array}$ & $\begin{array}{l}\text { Buy, build mass, derive } \\
\text { profit, leaves the } \\
\text { destination }\end{array}$ & $\begin{array}{l}\text { Obtained employment, } \\
\text { with or without } \\
\text { training }\end{array}$ & $\begin{array}{l}\text { Enjoy/has no limits, } \\
\text { at will }\end{array}$ \\
\hline Alter land use & $\begin{array}{l}\text { Get tax exemption, } \\
\text { deforestation, destroys } \\
\text { and builds }\end{array}$ & $\begin{array}{l}\text { Immigration, } \\
\text { generation of social } \\
\text { problems }\end{array}$ & $\begin{array}{l}\text { Leniency and } \\
\text { permissiveness to } \\
\text { contribute to the } \\
\text { altered environment }\end{array}$ \\
\hline \multicolumn{4}{|c|}{ Foreign exchange earnings } \\
\hline $\begin{array}{l}\text { Contributes to the } \\
\text { balance of } \\
\text { payments }\end{array}$ & $\begin{array}{l}\text { Promotions traced } \\
\text { throughout the country }\end{array}$ & $\begin{array}{l}\text { Meager wages, low or } \\
\text { no benefits }\end{array}$ & $\begin{array}{l}\text { Multiplier effect of } \\
\text { tourist spending }\end{array}$ \\
\hline \multicolumn{4}{|l|}{ Generation of jobs } \\
\hline $\begin{array}{l}\text { Temporary jobs/ } \\
\text { created } \\
\text { unions/violates } \\
\text { rights }\end{array}$ & $\begin{array}{l}\text { Excess supply, } \\
\text { devaluation of } \\
\text { destinations }\end{array}$ & $\begin{array}{l}\text { Acculturation, loss of } \\
\text { identity }\end{array}$ & $\begin{array}{l}\text { It creates } \\
\text { discrimination, } \\
\text { national tourism vs. } \\
\text { international tourism }\end{array}$ \\
\hline Floating population & $\begin{array}{l}\text { Creates jobs } \\
\text { multifunctional }\end{array}$ & $\begin{array}{l}\text { They emphasize social } \\
\text { classes, social } \\
\text { exclusion }\end{array}$ & $\begin{array}{l}\text { Exclusive tourism } \\
\text { to mass tourism }\end{array}$ \\
\hline $\begin{array}{l}\text { Boost to national } \\
\text { business }\end{array}$ & $\begin{array}{l}\text { Loose territorial } \\
\text { planning, growth } \\
\text { exceeds limits }\end{array}$ & $\begin{array}{l}\text { Living in areas at high } \\
\text { risk } \\
\text { or peripheral areas }\end{array}$ & $\begin{array}{l}\text { Involvement in the } \\
\text { deterioration of the } \\
\text { destination }\end{array}$ \\
\hline Regulations & $\begin{array}{l}\text { Ignores environmental } \\
\text { impacts }\end{array}$ & $\begin{array}{l}\text { Gets inadequate public } \\
\text { services (garbage } \\
\text { collection, drainage) }\end{array}$ & $\begin{array}{l}\text { All-inclusive } \\
\text { destinations to all } \\
\text { permitted }\end{array}$ \\
\hline Impacts & $\begin{array}{l}\text { Exhaustion of natural } \\
\text { resources/is not } \\
\text { responsible for } \\
\text { wastewater treatment. }\end{array}$ & $\begin{array}{l}\text { Bad service, } \\
\text { deterioration of the } \\
\text { tourist image, tourist } \\
\text { destinations mirror }\end{array}$ & $\begin{array}{l}\text { Sequel to excesses, } \\
\text { of the permissive } \\
\text { to the destructive }\end{array}$ \\
\hline
\end{tabular}




\section{Conclusions}

Environmental degradation is a constant throughout the planet, but this is accentuated in a stabbing in poor countries like Mexico, where regulations exist, however, corruption, tolerates changes in land use, prevailing devastation of ecosystems in environmental impunity

In Mexico the expropriation as a legal rule has allowed the dispossession of land to peasants, in a clear social exclusion of development, pushing them to marginalization, discrimination, integrating slums where it is considered prosperous tourism resorts

The Diamond Zone in Acapulco, Mexico is evidence that the regulation was never respected, established without water, drainage, wastewater treatment plants that are never evaluated by governments that characterized the greed and the need for quick cash, although that means ill coastal areas, which threaten the population and tourists.

The use and abuse of natural resources has caused severe damage to the natural balance aggression. This attack starts with the construction of new facilities and continued with the daily management and operation of the tourism industry.

The beaches and coastal natural resources are most in demand. Consequently, the impact on the conservation of beaches and water quality is important, especially while still giving priority to intensive development models.

The various global forums on how to stop all environmental risk in which they are cloistered Mexican coastal destinations which have failed humanity to be more prepared and conscious about the risks that threaten populations and coastal areas.

The sustainability programs have only been announced by the governments of countries to fulfill commitments to the various groups they are associated with, not caring to evaluate them, and in some cases even to implement them.

We believe that only from the school and the new generations of inhabitants of the countries of the earth can be achieved the consciousness change necessary to achieve the reversal of the effects of what we ourselves have caused.

It should ask the question: Do we have time?

\section{References}

[1] Orteiza, T., Acapulco, La Ciudad de las Naos del Oriente y de las Sirenas Modernas, Pandora editorial, 1 edición México D.F, pp.398-399, 1973.

[2] Escudero R., Origen y evolución del turismo en Acapulco, Editorial, Universidad Americana de Acapulco, H. Ayuntamiento de Acapulco, p. 64. 1997.

[3] Cruz, M. Salgado, M. Vázquez, O., Entrevistas a profundidad concretizada en la colonia de los viverístas, julio 23 del verano 2011.

[4] Zapata, P. Agatón D., (eds) Investigación aplicada para determinar impactos de segunda residencia en la Zona Diamante. Secretaria de Fomento Turístico del Gobierno del Estado de Guerrero. 2012. 
[5] Constitución Política de los Estados Unidos Mexicanos, Edición 2009. www. wikipedia.org./wiki/Expropiación

[6] Leff, E., (eds) Introducción a una visión global de los problemas ambientales en México. En Medioambiente y desarrollo en México CIIH. Universidad Nacional Autónoma de México, México. D.F. 1990.

[7] Escobar, A., El final del salvaje. Colombia: CEREC. ICAN, p.301, 1999.

[8] Velazco, R., Dirección de ecosistemas y ambientes costeros de la Secretaría de Medio Ambiente y Recursos Naturales (SEMARNAT) Periódico la El sur 28 febrero. p.24, 2012.

[9] Secretaria del Medio Ambiente y Recursos Naturales (SEMARNAT) www.semarnat.gob.mx./leyesynormas/pages/inicio

[10] Ahumada. A., Una estrategia para el desarrollo sustentable (Chapter 12) Ecoturismo y Turismo de Aventura en México, Normatividad y legislación, Comisión de Turismo, Cámara de diputados L1X Legislatura. p.105, 2006.

[11] Comisión Nacional del Agua (CONAGUA) es el organismo encargado de administrar y preservar las aguas nacionales en México. www.wikipedia.org/wiki/CONAGUA

[12] Pereyra, A., Goldwasser, B., Soria. Degradación y riesgo ambiental en algunos barrios del eje norte de la región, metropolitana de Buenos Aires. Proc. X11 Encuentro Humboldt. eds. Argentina. pp.1-12, 2010.

[13] Bernard, A., Turismo Patrimonio y Desarrollo, Confederación Panamericana de Escuelas de Hotelería y Turismo.( CONPEHT) México, p.5, 2008.

[14] Leff, E., Saber Ambiental., Sustentabilidad, Racionalidad, Complejidad, Poder.- Siglo XX1 editores, S.A. de C.V. México, D.F, p.68, 2002.

[15] Ley General de Equilibrio Ecológico y Protección al Ambiente. www.redindigena.net/leyes/mex/docs/2/equileco.html

[16] Norma Oficial mexicana-NOM-022-SEMARNAT-2003. Www.dof.vlex.com.mx/vid/preservacion-humedales-costeros-manglar$\underline{28051107}$

[17] Cumbre de la Tierra de Rio de Janeiro, Brasil 1992- 03 al 14 de junio 1992. Es.wikipedia.org./wiki/cumbre de la tierra de Rio de Janeiro

[18] Plan Nacional de Desarrollo PND-2007-2012-Turismo. pnd.calderon.presidencia.gob.mx/economía-competitiva-y-generadora-deempleos/turismo.html

[19] Cardona, O., Manejo Ambiental y preservación de desastres, dos temas asociados. En Maskrey, A. Los desastres no son naturales. La red ITDG. Bogotá, Colombia. Cap. 4. 1996.

[20] Jiménez M .A., Legislación mexicana en torno a la actividad turística, en Teoría y Praxis, Universidad de Quintana Roo. p.104. 2007.

[21] Arias, X.C., La formación de la Política Económica._Civitas, Madrid. España.1996.

[22] Kauffer, M. E.,(eds) Las políticas públicas: algunos apuntes generales. Colegio de la Frontera Sur. Chiapas, México. 2008.

[23] Foley, J., Límites de un planeta sano.-Instituto de Medio Ambiente de la Universidad de Minnesota, en la revista Investigación y Ciencia. España. Junio. pp. 23-28, 2010. 